\title{
Articles
}

Central European Review of Economics \& Finance

Vol. 19, No. 3 (2017), pp. 43-56. D0I: 10.24136/ceref.2017.012

Kalina Maj ${ }^{1}$

\section{CIVIC INITIATIVE - BETWEEN SOCIAL AND MARKET ASPECT OF THE TERRITORIAL AUTONOMY'S ECONOMY ON THE EXAMPLE OF RADOM CITY}

The subject of this consideration is the validity of existence and functioning of the direct mechanisms responsible for political decisions which are manifested in the process of the civic initiative - the most popular form of civic participation defined as the citizens' share in making decisions by the authorities. The goal of this work is to answer the question about the role and perspective of the civic initiative's progress as a tool of the citizens' effect on the decisions considering placing the wherewithal on the specific local investments. The issue of the civic participation, its mechanisms and the principles of its action presented in this project is discussed on the example of Radom city.

JEL Classification Codes: H72.

Keywords: social participation, citizens' initiative, citizens' budget, local government, consultations, democracy.

\section{Introduction}

It is easy to notice that there has been a systematic tendency among the citizens to decrease of sharing elections to the government representatives and an unwillingness to go in for political parties for several tens of years. Moreover, there is an opinion that the citizens' level of trust to public institutions and democratic mechanisms (Długosz, Wygnański, 2005, p. 4) is

\footnotetext{
${ }^{1}$ Master of Law, Kazimierz Pulaski University of Technology and Humanities in Radom, Poland.
} 
declining. At the same time, the meaning of the civic organizations which are ideologically differentiated and work in a various levels is rising (Wright, 1994, p. 102-137). Finally, it can lead to crisis of the mechanisms responsible for the functioning the country as a unit sometimes called "the deficit of the democracy" ${ }^{2}$ (Nentwich) therefore the most of the citizens claims that the "authority" - chosen representatives - does not embody them.

The participation, defined as taking part - contribution in a bigger group, project or investment. Generally it is identified as an active taking part of a local society in the process of the public issues' management. Specifically, it comes down to citizens' direct activity while making political decisions (Sakowicz, KSAP XVIII p. 5). This term is firmly associated with democratic theories which are related to the participation in making decisions, cooperation among investments and society. The concept of social participation very often applies to the institution of „participated democracy” which relies on socializing of the administration of towns' and districts' budget. Participatory democracy is regarded as one of the form of direct democracy's implementation, or the governments without factoring of chosen representatives (Urban, 2009, p. 102) - „people's authority”.

The fact that a decline of the trust to political representatives is real is best shown by the scientific researches made for that aim. The results of comparing analysis done in March 2011 in five European countries indicate that only 29\% respondents in United Kingdom and even less in Poland - only 16\% "trust the government is able to solve its country's problems"3 (http://www. guardian.co.uk and http://centrumwspolpracy.org.pl/). In the same study $12 \%$ of British people claim that they acknowledge that politicians behave in a honest and right way while in Poland such opinion was presented by only $3 \%$. Due to such negative results the attention was paid on the problem of decreasing voter turnout and low trust to public institutions. Creation of the possibility for citizens to take part in debates and express their own opinions about the decisions made by authorities became an important point. The

\footnotetext{
${ }^{2}$ „Democratic deficit” - the definition proposed by Michael Nentwich, referring to public participation in political participation UE, using the terms „opportunity structures for citizens Participations” and „political opportunity structures”, it indicates that an organization such as the European Union provides ample opportunities for the participation of citizens in the creation of power, making decisions that are not used.

3 The Guardian ICM. Examined a random sample of 5023 adult respondents in five EU countries (UK, France, Spain, Germany, Poland) aged 18-64 years using the online dashboard in the period from 24 February to 8 March 2011.
} 
initiative or the civil participation ${ }^{4}$ (Kalina-Prasznic, 2001, p. 139) means conscious citizens' involvement in creating the decisions made by the representatives of national authority. For reaching that target there is a need for representatives of the government to start a dialogue between them and citizens which can lead to contribution of politics that is led by the government.

The civic participation in that shape means much more than only taking part in vote once a several years. Civic discussion as well as negotiations between the citizens and the authority about the way of public goods' redistribution are the essential parts of participated budgeting (Wampler, 2007). In practice that discussion should be realised by a permanent cooperation between the administration and the citizens based on mutual analyse of the problems and seeking for possible solutions (www.centrumwspolpracy.org.pl/).

\section{The origins of the idea}

The history of the participated budget is not long. The concept was created quite recently - in 90s of XX century. It can be surprised that not in Europe but in south-eastern town of Brazil - Porto Alegre. The goal of the civil initiative was not to enhance the democracy but to lead to varied social changes. Their aim is to initiate a long-term social reform consisting in the change of financial resources' redistribution at the city level. The most of south American cities that decided to apply the participated budget, was struggling with a lot of basic social and economic problems. In these cities there were big social disproportions in a range of the life standards causing extreme poverty which led to growth of the crime factor. Implementation of the participated budget there played a significant role causing involvement excluded social groups in the process of local issues' management which meant better and clearer system of city finances' disposal. A new solution had also an important psychological meaning because it contributed to building among citizens a sense of co-responsibility for the city they lived in. The participated budget was to increase the effectiveness of spending budget resources, to reduce wasting of money and to bring citizens' trust to authorities back (Sadura, 2013, p. 11).

The participated budget in Porto Alegre has turned to be a great success for years. In 1990, which was the first year of its functioning, in public assemblies there were only 976 citizens who took part, while in 2004 in the deci-

\footnotetext{
${ }^{4}$ The idea of participatory democracy derives from the koncept of Jean Jacquesa Rousseau.
} 
sion process there were 50000 involved people who participated in official district and thematic assemblies (Górski, 2005 p. 20). What is essential, in the whole process the big share belonged to the poorest and jobless citizens who are rather unwilling to active involvement in a public life. On the organised assemblies the citizens were debating for example about: the housing economy, tourism, the social assistance, health, education, culture and spare time. Afterwards, they indicated main areas for particular district. Very important element of the participated budget was politics which informed about spending public money. Since 1990 in Porto Alegre the net of agencies that informs about the structure and factors of the budget, administrative supplies and investment plans has been functioning (Górski, 2005, p. 10). Moreover, each year the city officers are obliged to show the reports from accomplishment of the last year budget to the citizens. Positive effects of introducing the participated budget in Porto Alegre were for instance:

- generalisation of the access to water and electricity

- due to rising number of the students in elementary and secondary schools to $240 \%$, the percentage of illiterates was the smallest in Brazil

- giving $98 \%$ of citizens sewage system, which had only $49 \%$ before

- the indicator of the average length of life exceeded national norms, the lowest death rate among infants in the country

- implications for the budget from local taxes grew for ages to 144\% (Górski, 2005 p. 26-30).

Social participation in that shape first became widespread throughout the whole Brazil, where till 2008 this solution was introduced in about 200 cities. Therefore, the possibility to co-decide about expenses was obtained by more than 44 million of citizens from that country (Kłębowski, 2013, p. 11). At the start of 2000 the attempts to implement the participated budget was made in Europe: United Kingdom - 2000, France - 2002, Spain - 2003. The participated budget became very popular with the whole world very fast. Outside the European areas it appeared also in Africa, Asia and North America (Głąbicka, Śwital, 2016, p. 348). It was not only used for changing the civic politics but also for solving certain problems of specific social groups.

\section{Polish rules and regulations}

The first display of the initiative ideologically regarding to issues of the civic participation appeared in Płock ${ }^{5}$ between 2003-2005. The project con-

${ }^{5}$ Płock - city located in Mazowieckie, Poland. 
ducted by the City Hall in Płock, PKN Orlen and United Nations was to create so-called "grant fund" thanks to which local non-governmental organisations had possibility to apply for funding of their projects. (Głąbicka, Śwital, 2016, p. 349)

The idea of the introducing the first participated budget in Poland occurred in 2010 (some reports claim it was 2011) thanks to the Developmental Initiative in Sopot (www.sopockainicjatywa.org) informal organisation that functions in Sopot in favour of realisation of demands regarding balanced development and growth of citizens' participation in making decisions concerning themselves (Kraszewski, Mojkowski, 2014, p. 8). At first, the concept had not so many followers among the representatives of the city authorities. As a result of educational and promotional activities made by the Developmental Initiative in Sopot the City Council decided by vote a resolution that introduced mechanism of the participated budget. They wrote down a plan concerning putting under civil expenditure which stands about $1 \%$ of the all city budget's expands (about 3 million PLN). What is more, they convened the ad hoc Commission of the City Council for the civil budget that gave attention to formulation of the procedure of introducing the citizens' budget in Sopot. (Kraszewski, Mojkowski, 2014, p. 26).

The citizens' budget - such name was given to the civic participated initiative - was introduced in more than 70 communes and cities in Poland. In 2013 almost 40 cities in Poland fulfilled the participated budget as well as they planned a part of expands for 2014. cities were as follow: Białystok, Chorzów, Dąbrowa Górnicza, Elbląg, Gdańsk, Gliwice, Gorlice, Gorzów, Jaworzno, Kargowa, Kędzierzyn-Koźle, Koszalin, Kielce, Kraków, Legnica, Łódź, Milicz, Mrągowo, Olsztyn, Piekary Śląskie, Płock, Poznań, Radom, Rawicz, Ruda Śląska, Rybnik, Sopot, Starachowice, Słupsk, Stargard Szczeciński, Szczecin, Świętochłowice, Tarnobrzeg, Tarnów, Wałbrzych, Włocławek, Wrocław, Zielona Góra (Kraszewski, Mojkowski, 2014 p. 5-6).

\section{Law aspects}

Self-governments in Poland create budgets on the basis of approvals of the district council and executive organ's edict. Civil budgets realised in polish cities became contests of the citizens' projects which were funded by assigned parts of the budget - mostly about $1 \%$ of the whole city budget.

The civil budget is introduced according to Article 5a Law of communal self-government (Dz. U. 2016 poz. 446, 1579) on the basis of which in case of occurrences provided for the law or other important for communes issues 
the consultations with the citizens may be carried out. The budget resolution accepted by the representative organ of the commune constitutes legal basis and authorisation for financial economy's management in particular budget year. (Borodo, 2008, p. 242)

Self-government enactment as well as the rules of the enactment of public finance do not regulate the issues about citizens' taking part in the procedure of the commune's budget creating and co-deciding about spending its financial sources. The organs of commune are obliged to deal with the enactments such as a village head (a mayor or a president) and the city council. The executive organ develops the budget project and shows it to the council within a particular time frame restricted by the law of the public financials until $15^{\text {th }}$ of November the previous budget year. Whilst according to Article 18 (2) point 4 of the self-government law the city council is obliged to enact the commune budget, examine reports from its functioning and make a resolution as providing discharge for that. Therefore, the regulations of the self-government budget procedure do not add the legal basis to working on so-called the participated budget. (Czarnecki, 2014)

Essential is fact that the civil budget is not exactly like social consultations. Despite the fact that both institutions are not combining for authorities. As far as the citizens' budget is concerned, the citizens however have some guarantee that their willing will be respected and the project chosen by them will be funded next budget year. Generally, in the case of civil initiative process the commune authorities declare that citizens' decisions will be approved. Such solution is only a social deal between the authorities and the citizens. Attitude like that may cause a lot of doubts to begin with the fact that the social deal does not combine both fronts effectively but is based only on goodwill in fulfilling promises. That is why councillors who do not abide by the deal laws do not have to bear any consequences. It would have sense only if the councillors suffered the consequences of not fulfilling the points of deals for instance not agreeing with citizens' proposals about introducing budget offers to the council in accordance with the deal. However, the councillor's mandate is a free mandate; therefore, there is no possibility to make deals concerning the way of fulfilling the mandate by the councillor. In that case the citizens do not have any legal means which can help them to exert gratifying the promises made by the authorities when they do not fulfill assignments chosen by the citizens. The only sanction for not fulfilling restricted issues from the civil budget which the citizens absorb is not voting for specific authorities in self-government vote or organising an appeal referendum. It is appropriate to mention that there was not any case of not fulfilling the deal so far. (Kraszewski, Mojkowski, 2014, p. 8). 


\section{The civil initiative in Radom - first projects}

The subject matter concerning the participated budget in Radom which regards putting forward citizens' points of view about specific investments was initiated in 2013. However, earlier because in 2012 the city authorities chaired meetings with citizens involving postulates about modernisation and city resources' improvement. The civil budget was assumed to occur as a sort of social consultations in support of spending part of the budget of the Commune's of City Radom on indicated by the citizens' local purposes. Within the limits of the participated budget the citizens who have the rights to vote were able to get involved in the choice of investments which should be realized as a part of the city budget put at disposal by them.

On $21^{\text {st }}$ of January 2013 city council in Radom adopted a resolution number $472 / 2013$, which introduced the procedure that regulates rules of social consultation in Radom in general. Its aim is to regulate the legal issues of the social participation in the active managing of the city. The main goal was to define the rules and procedures of conducting social consultations with the inhabitants of the city, it also indicated the term of social consultations and their purpose. That is why the proposed resolution of the definition of social consultation should rely on:

- expression an opinion, submit comments and proposals to the matters subject of consultation,

- providing responses for questions,

- selecting one of the proposed solutions (Uchwała nr 472/2013 Rady Miejskiej w Radomiu z dnia 21 stycznia 2013 r.).

The most important goal of public consultations with the citizens was to strengthen the mechanism of the civil participation concerning important issues for every citizen. It causes at the same time active cooperation of local authorities and citizens in making a modern civil society more popular, raising civic awareness and responsibility for local issues (www.konsultacje. radom.pl). The purposes in this act were identical and relied on:

- including the residents in the process of city management,

- expressing citizens' opinions about the matter of the consultations,

- obtaining public understanding and acceptance for proposed solutions,

- building the civil society.

Moreover, a form of consultation was identified and it formed:

1) an open meeting with residents

2) meeting with the representatives of social and professional groups, nongovernment organisations and other groups conducting charitable activities for the benefit of residents 
3) receiving opinions and proposals in a form of a paper of electronic survey. (Uchwała nr 472/2013 Rady Miejskiej w Radomiu z dnia 21 stycznia 2013 r.)

The decision-making process of the participated budget was divided into two stages. In the first stage the residents reported their proposals to the city budget by completing a registration form. Firstly, they filled the form and next they sent it to the City Hall. The citizens had to define the purposes of their project, a short description, and estimated costs in this form. Then all the submitted forms were given to departments where they were analysed mainly focusing on the legal possibilities of the investment as well as the economy, and the possibility of securing funds for the idea in the upcoming years. The cost of each project cannot go over 600000 PLN. Next the verified substantive projects with descriptions and recommendations were submitted by the offices of the president (the Centre of social communication) to the opinionated team that analysed these projects on the basis of the recommendations and it developed a final list of the residents' projects to vote. ( Załącznik nr 1 do Zarządzenia nr 77/2015 Prezydenta Miasta Radomia z dnia 7 stycznia 2015 r.). The list of all received projects, both of these matching the conditions and those not matching, was given to the public information.

The second stage was the residents' voting on reported and verified projects. The projects were evaluated in a secret vote. Every resident of Radom who graduated 16 years has the right to participate in the voting. The voting is carried out within the prescribed time schedule and special prepared cards to vote in the indicated areas in the city (Załącznik nr 1 do Zarządzenia nr 77/2015 Prezydenta Miasta Radomia z dnia 7 stycznia 2015 r.). Residents of Radom voted on the basis of lists of votes when they shown their ID card. Voters could choose five the most interesting and most important projects. After verification of those applications this projects which obtained the most votes were introduced into the budget for the next year, until the budget funds were used for their realization. These funds were allocated differently in various cities (for instance in Sopot it was 6 million PLN, in Poznań 10 million PLN, in Elbląg 2 million PLN) (www.radom.pl).

Public consultation concerning the participated budget give the residents opportunity to comment about spending part of the financial resources of the community on specific investment, renovation or other works. The participated budget is in fact a plan to divide a certain amount of money included in the budget of the commune, about which residents can discuss in the form of social consultation (Borodo, 2008, p. 248-249). 


\section{Citizen's initiative in Radom in successive councils}

In 2014 the total amount of the civil budget was 3 millions PLN. It means that each of the project from the five electoral districts was worth 500 thousand PLN. The same sum of money, also 500 thousand PLN, was given to the citywide project (www.radom.pl).

In 2015 this amount increased and estimated 4 million and 200 thousand. Therefore each area received 700 thousand PLN. It is a big difference with comparison to the previous year.(www.radom.pl) The sum allocated in the city budget for the civic budget in 2016 already amounted 4 million 800 thousand PLN ${ }^{6}$ giving 800 thousand PLN. to the projects of each of the five areas and 800 thousand PLN for citywide project. (Zarządzenie nr 77/2015 Prezydenta Miasta Radomia z dnia 7 stycznia 2015 r.)

The winning projects were divided according to five areas. The following tables present the projects which were included in the following areas (https:// konsultacje.radom.pl).

Table 1. The winning project in the area of the whole city- area "0"

\begin{tabular}{|c|l|c|c|c|}
\hline No. & \multicolumn{1}{|c|}{ The venture project } & $\begin{array}{c}\text { Number } \\
\text { of voters }\end{array}$ & Total points & $\begin{array}{c}\text { Estimated cost } \\
\text { (thousand PLN) }\end{array}$ \\
\hline 1 & Good house - place of concern for the human psyche & 2685 & 12625 & 100 \\
\hline 2 & Ambulance for citizens of Radom & 2280 & 10836 & 500 \\
\hline 3 & Parks bespattering against mosquitoes and ticks & 1968 & 9121 & 200 \\
\hline
\end{tabular}

Source: The author's own compilation.

Table 2. The winning projects in the area number 1

\begin{tabular}{|c|l|c|c|c|}
\hline No. & \multicolumn{1}{|c|}{ The venture project } & $\begin{array}{c}\text { Number } \\
\text { of voters }\end{array}$ & Total points & $\begin{array}{c}\text { Estimated cost } \\
\text { (thousand PLN) }\end{array}$ \\
\hline 1 & Playgrounds for primary school numb 13 & 3280 & 15909 & 600 \\
\hline 2 & $\begin{array}{l}\text { Modernization of land for recreational and sport } \\
\text { purposes for children, teenagers and adults }\end{array}$ & 2637 & 12677 & 200 \\
\hline
\end{tabular}

Source: The author's own compilation.

\footnotetext{
${ }^{6}$ Although the cost of individual projects in some areas exceeded the estimated cost for the proposed area of 800 PLN. The civic budget finally fit in the assumed total of 4800000 PLN.
} 
Table 3. The winning projects in the area number 2

\begin{tabular}{|c|l|c|c|c|}
\hline No. & \multicolumn{1}{|c|}{ The venture project } & $\begin{array}{c}\text { Number } \\
\text { of voters }\end{array}$ & Total points & $\begin{array}{c}\text { Estimated cost } \\
\text { (thousand PLN) }\end{array}$ \\
\hline 1 & $\begin{array}{l}\text { Bike paths on the Ustronie estate } \\
\text { and on the Grzecznarowskiego Street }\end{array}$ & 1580 & 7319 & 600 \\
\hline 2 & $\begin{array}{l}\text { New books for the libraries, increasing of the library } \\
\text { branch no. 14 and 15 }\end{array}$ & 798 & 3366 & 100 \\
\hline 3 & $\begin{array}{l}\text { Fit children - healthy children. Zone of physical } \\
\text { activity and rest in a primary school no. 4 in Radom }\end{array}$ & 807 & 3329 & 200 \\
\hline
\end{tabular}

Source: The author's own compilation.

Table 4. The winning projects in the area number 3

\begin{tabular}{|c|c|c|c|c|}
\hline No. & The venture project & $\begin{array}{l}\text { Number } \\
\text { of voters }\end{array}$ & Total points & $\begin{array}{l}\text { Estimated cost } \\
\text { (thousand PLN) }\end{array}$ \\
\hline 1 & $\begin{array}{l}\text { A multipurpose sports field and running track } \\
\text { on the Wośniki estate }\end{array}$ & 2261 & 10810 & 600 \\
\hline 2 & $\begin{array}{l}\text { New books for the library, increasing } \\
\text { of the library branch No. } 9,12,16\end{array}$ & 859 & 3784 & 100 \\
\hline 3 & By foot and safe & 696 & 2890 & 100 \\
\hline 4 & $\begin{array}{l}\text { Equipment fencing, and change of the location } \\
\text { of the playground on the Podkanów estate } \\
\text { in Odlewnicza } 2 \text { Street }\end{array}$ & 577 & 2359 & 100 \\
\hline
\end{tabular}

Source: The author's own compilation.

Table 5. The winning projects in the area number 4

\begin{tabular}{|c|l|c|c|c|}
\hline No. & \multicolumn{1}{|c|}{ The venture project } & $\begin{array}{c}\text { Number } \\
\text { of voters }\end{array}$ & Total points & $\begin{array}{c}\text { Estimated cost } \\
\text { (thousand PLN) }\end{array}$ \\
\hline 1 & $\begin{array}{l}\text { Development of green objects in Maria Konopnicka } \\
\text { high schoolin Radom }\end{array}$ & 2218 & 10535 & 300 \\
\hline 2 & $\begin{array}{l}\text { Continuation of the construction and enlargement } \\
\text { of the Gotębiów park-gym, fitness, new trees and } \\
\text { walking and cycling paths }\end{array}$ & 1470 & 6886 & 300 \\
\hline 3 & $\begin{array}{l}\text { Transformation of several rooms in the primary school } \\
\text { public recreation and sports complex for Kaptur, } \\
\text { Zamłynie, Wacyn estate }\end{array}$ & 793 & 3411 & 100 \\
\hline 4 & $\begin{array}{l}\text { New books for the library, increasing of the library } \\
\text { branch No. 3, 4. }\end{array}$ & 678 & 3784 & 100 \\
\hline 5 & Outsidegym in Mroza Street in Radom & 571 & 2486 & 100 \\
\hline
\end{tabular}

Source: The author's own compilation. 
Table 6. The winning projects in the area number 5

\begin{tabular}{|c|l|c|c|c|}
\hline No. & \multicolumn{1}{|c|}{ The venture project } & $\begin{array}{c}\text { Number } \\
\text { of voters }\end{array}$ & Total points & $\begin{array}{c}\text { Estimated cost } \\
\text { (thousand PLN) }\end{array}$ \\
\hline 1 & $\begin{array}{l}\text { Construction of pedestrian paths and bicycle } \\
\text { paths along the Energetyków, street between } \\
\text { Stara and Nowa Wola Golębiowska }\end{array}$ & 1740 & 8251 & 600 \\
\hline 2 & $\begin{array}{l}\text { New books for the library, increase the library } \\
\text { branch No 1, 2 }\end{array}$ & 785 & 3360 & 100 \\
\hline 3 & Gym under the sky & 720 & 3036 & 100 \\
\hline
\end{tabular}

Source: The author's own compilation?

\section{Citizen's initiative in Radom - plans for the future}

Certainly, the civil budget will be continued in following years owing to the fact that it is very popular and it has positive effects. It should be noted, that the procedure for its preparation is not easy and requires involvement of many resources and the work of a lot of clerks. Basically, it is not really appropriate to define it as a method of direct deciding about the city issues. It should be called the "half-direct” method or the „indirect” system of deciding concerning versatility of proceedings and activities of the Commission that gives opinions about the projects which excludes most proposals. Nevertheless, the design of the social participation should be assessed positively because it is not only motivates the commune, the city but also has many positive effects on economic and social sphere. It improves thrift and supports the proper usage and allocation of financial resources.

In 2017 projects for implementation under the civil budget also was divided according to six areas. Within citywide project there will be realized for instance: first aid for anyone, literary and theatrical workshops, mobile museum of antique bicycles, the new car-parking spaces in Radom, bespattering parks in the city against mosquitoes and ticks, "cancer backwards”, the informative and aid campaign, free bikes transport - health and ecology. In the first region the projects which was approved are as follow: the revitalization of the area - the renovation of the square, the playground, the construction of parking spaces, replacement of lighting, jogging for health - free "nordic walking” classes, exposing the most valuable monument of Radom by its illumination and safe pavement and bicycles path to the station. The

\footnotetext{
${ }^{7}$ Tables No. 1, 2, 3, 4, 5, 6 have been developed on the basis of the data contained in Appendix 5 to report on the public consultation on the so-called. Citizens' budget of Radom for 2016.
} 
second area was obtained such initiative: renovation of the gym in primary school No. 9 in Radom and the expansion of the gym and outdoor playground in the "Ustronie" park. The third area gained as much as 8 new projects: the construction of "Skrajna” Street lighting, cheerful mini playground, fitness park in primary school No. 26, „laboratory space”, "brighter way to home”, the improvement of communication in "Południe” estate. In the fourth area the residents decided to create an inter-generational club of initiatives, cycling paths in three urban neighborhoods and support the development of new green areas on the outskirts of "Gołębiów” estate. In the last five area most points were gained by the following projects: the construction of the tool for the long jump in the primary school No. 20 in Radom, bike paths in the "Gołębiów” and "Glinice” estates and introduction of a „cultural meeting by the stream". (Załącznik nr 6 do sprawozdania z konsultacji społecznych dotyczących Budżetu Obywatelskiego Miasta Radomia na 2017 r.)

\section{Conclusions}

Building a development strategy involving the introduction of far-reaching changes should be based largely on human perceptions which have a major impact on creating the vision of the development and the willingness of its realization. The most essential role is played by the local government, which should be the inspiration and the moderator of an activity of the citizens, that aims to develop collective agreements regarding solving social problems.

Owing to the institution of citizens' initiative, citizens have much greater opportunities to participate in the process of creating the projects that are undertaken in their communities. Special dimension becomes a principle of democracy as one of the basic constitutional principles. In the most general terms, it is considered as a democratic system in which power is exercised by "demos” which means people (Mik, 2000, pp. 414-438). Despite the fact that such understanding of democracy is reflected in the constitutions of several countries, the authorities extreme rarely realise it directly ${ }^{8}$.

The reference to dreams and creativity of the citizens themselves should be the overriding criterion in the process of creating the policy of the civil society's development and strengthening its structures. The civil budget is a very important and necessary initiative.

\footnotetext{
${ }^{8}$ Preamble of the Polish Constitution: „[...] We, the Polish Nation - all citizens of the Republic ...” art. 4 of the Constitution: „1. Supreme power in the Polish Republic belongs to the Nation. 2. The Nation shall exercise such power through their representatives or directly "
} 


\section{References}

Borodo, A. (2008). Samorząd terytorialny. System prawnofinansowy, wyd. 6, Warszawa

Czarnecki, K. (2014). Udział mieszkańców w ustalaniu wydatków budżetu gminy w ramach tzw. budżetu partycypacyjnego (na przykładzie Torunia w latach 2013-2014) artykuł w Prawo Budżetowe Państwa i Samorządu 1(2)/2014

Długosz D.J., Wygnański J. (2005). Obywatele współdecyduję, Przewodnik po partycypacji społecznej, Stowarzyszenie na rzecz Forum Inicjatyw Pozarządowych, Warszawa.

Głąbicka K., Śwital P. (Ed) (2016). Partycypacja społeczna w samorządzie terytorialnym - aspekty prawne, ekonomiczne, społeczne. Instytut NaukowoWydawniczy „Spatium”, Radom

Górski R. (2005). Przewodnik po demokracji uczestniczącej/partycypacyjnej, Poznań-Kraków.

http://centrumwspolpracy.org.pl/wp-content/uploads/2014/11/budzet-partycypacyjny.pdf (accessed 17.11.2016 r.).

http://www.bip.radom.pl (accessed 26.11.2016 r.).

http://www.guardian.co.uk/news/datablog/2011/mar/14/europe-poll-icm\#data (accessed 17.11.2016 r.).

http://www.radom.pl/page/3536,razem-o-budzecie-miasta-na-2015-rok. html (accessed 26.11.2016 r.).

http://www.sopockainicjatywa.org/ (accessed 17.11.2016 r.).

https://konsultacje.radom.pl/page/14,konsultacje-spoleczne.htmlhttp:// www.radom.pl/page/2835, razem-o-budzecie-miasta-na-2014-rok.html (accessed 26.11.2016 r.).

https://konsultacje.radom.pl/page/145,zwycieskie-projekty-budzetu-obywatelskiego-2016.html (accessed 26.11.2016 r.).

Kalina-Prasznic U. (Ed.)(2001). Encyklopedia prawa, Warszawa.

Kłębowisk W. (2013). Budżet partycypacyjny. Krótka historia obsługi, Instytut Obywatelski, Warszawa.

Kraszewski D., Mojkowski K.(2014). Budżet Obywatelski w Polsce, Fundacja im. Stefana Batorego Warszawa.

Mik C. (2000). Europejskie prawo wspólnotowe. Zagadnienia teorii i praktyki, t. 1, Warszawa.

Nentwich M. Opportunity structures for citizens' participation, [w:] A. Weale A., Nentwich M. (Ed.), Political Theory. 
Sadura P. (2013). Podzielmy się kulturą. Budżet partycypacyjny w Domu Kultury Śródmieście. Opis procesu wraz z rekomendacjami, Fundacja Pole Dialogu, Warszawa.

Sakowicz M. Partycypacja społeczna w działaniu administracji na tle rozwiązań w państwach Unii Europejskiej - prace analityczne słuchaczy KSAP XVIII Promocji (Ed.) M. Sakowicz, Krajowa Szkoła Administracji Publicznej, Warszawa.

Uchwała nr 472/2013 Rady Miejskiej w Radomiu z dnia 21 stycznia 2013 r. w sprawie zasad i trybu przeprowadzania konsultacji społecznych na terenie Miasta Radomia.

Urban A. (2009). Bezpieczeństwo społeczności lokalnych, Warszawa.

Ustawa z dn. 08.03.1990 r. o samorządzie gminnym, Dz. U. 2016 poz. 446.

Wampler B. (2007). Participatory Budgeting In Brazil Cooperation and Accountability, Pensylvania State Uniwersity Press PA.

Wright V. (1994). Reshaping the State, The Implication for Public Administration (Ed.) W. Muller, V. Wright, The State in Western Europe. Retreat or Redefinition? Special Issue if West European Politics, Vol. 17, No. 3

Załącznik nr 5 do sprawozdania z konsultacji społecznych dotyczących tzw. Budżetu Obywatelskiego Miasta Radomia na 2016 r.

Załącznik nr 6 do sprawozdania z konsultacji społecznych dotyczących tzw. Budżetu Obywatelskiego Miasta Radomia na 2017 r.

Zarządzenie nr 77/2015 Prezydenta Miasta Radomia z dnia 7 stycznia 2015 r. w sprawie: przeprowadzenia na terenie Miasta Radomia konsultacji społecznych dotyczących tzw. Budżetu Obywatelskiego Miasta Radomia na rok 2016. 